\title{
Plasma $\beta$-Casomorphin-7 Immunoreactive Peptide Increases after Milk Intake in Newborn but not in Adult Dogs
}

\author{
MALATHY SINGH, CAROL L. ROSEN, KWEN JEN CHANG, AND GABRIEL G. HADDAD \\ Department of Pediatrics (Pulmonary Division), Columbia University College of Physicians and Surgeons, New \\ York, New York 10032; and Division of Cell Biology, Burroughs Wellcome Co., Research Triangle Park, \\ North Carolina 27709
}

\begin{abstract}
To determine the relation between milk intake and plasma levels of $\beta$-casomorphins as a function of age, we studied the levels of $\beta$-casomorphin-7 immunoreactive material (BCMIR) in 2 - and 4-wk-old beagle neonates and adult dogs following milk intake. We used three kinds of milk: 1) bovine casein-based milk formula; 2) canine bitch's milk, and 3) soy protein-based (noncasein) formula. Using a new extraction technique, BCMIR was isolated from plasma and assayed by radioimmunoassay at $0,2,4$, and $6 \mathrm{~h}$ after feeding. We found that BCMIR increased significantly in both 2- and 4-wk-old puppies post bovine and canine milk feeding, but not after soy protein formula. Base-line values were about 80-120 fmol/ $\mathrm{ml}$ and increased to $100-120 \% 2 \mathrm{~h}$ after bovine casein intake in the older puppies and by $4 \mathrm{~h}$ in the younger group. BCMIR levels were undetectable in adult dogs before or after bovine milk feeding. $\beta$-casomorphin- 7 added to plasma was rapidly degraded whereas BCMIR was stable. Chromatographic profiles demonstrated that the BCMIR moiety is larger than $\beta$-casomorphin-7. Our data suggest that the appearance of BCMIR in the plasma of neonatal dogs is a result of $\beta$-casein degradation along a permeable gastrointestinal mucosa. We speculate that morphiceptin and $\beta$-casomorphins can be cleaved from BCMIR and may have important physiologic effects. (Pediatr Res 26: 34-38, 1989)
\end{abstract}

\section{Abbreviations}

BCMIR, $\beta$-casomorphin-7 immunoreactive material TFA, trifluoroacetic acid

Recently, peptide fragments of $\beta$-casein, a major milk protein, have been shown to possess opioid activity (1). These peptides, known as $\beta$-casomorphins and morphiceptin, exhibit selective $\mu$ opioid receptor activity like that of morphine $(2,3)$. For example, $\beta$-casomorphins have been shown to induce analgesia (4), influence pancreatic function $(5,6)$, depress cardiorespiratory function (7), and alter behavior (8).

Even though the mechanism of cleavage of this peptide from

Received October 17, 1988; accepted March 23, 1989.

Correspondence: Dr. G. G. Haddad, Department of Pediatrics, Division of Respiratory Medicine, Yale University School of Medicine, 333 Cedar Street, New Haven. CT 06510

Supported by Grant HD15736 and Training Grant HL07421 of the National Institute of Health. G.G.H. is an Established Investigator of the American Heart Association. $\beta$-casein is not known, formation of $\beta$-casomorphin immunoreactive material has been demonstrated in the intestine of animals (9) and adult humans (10) after milk ingestion. $\beta$ casomorphin immunoreactivity was also present in the plasma of newborn calves (11) but not in adult human plasma after milk intake (12).

Because the intestinal mucosa of the newborn is known to be more permeable than that of mature subjects (13), it is possible that molecules of the size of $\beta$-casomorphins get absorbed in early life but not in adult individuals. The presence of such molecules in the plasma of the newborn may be very significant since the blood brain barrier can be permeable (14) and these substances can reach the CNS. To study the relation between milk intake, plasma levels, and postnatal age, the present experiments were undertaken. We used neonatal and adult dogs, a new extraction procedure and an RIA, and found that BCMIR levels increase in newborn but not in adult dogs after milk intake.

\section{MATERIALS AND METHODS}

Chemicals. $\beta$-casomorphin-7 and thiorphan were purchased from Peninsula Laboratories, Inc. (Belmont, CA). All other chemicals were products of Sigma Chemical Co. (St. Louis, MO). $\mathrm{Na} \mathrm{I}^{125}$ was bought from Amersham Corp. (Arlington Heights, IL) and solvents were HPLC grade and were obtained from Fisher Scientific Co. (Pittsburgh, PA).

Animal experimental protocol. Pregnant beagles were purchased from Marshall Farms (North Rose, NY), 10-12 days before term and were housed in the animal facility. A total of 20 puppies (derived from eight litters, age 2 and 4 wk), and three adult dogs were used for the study. Ten puppies were used for bovine formula, five for canine milk, and five others for soy protein milk. Under anesthesia (Halothane, $\mathrm{N}_{2} \mathrm{O}$ ), a catheter was placed in the femoral artery $2 \mathrm{~d}$ before study. In general, the same puppies were used at 2 and 4 wk of age using different arteries. After ensuring a fast of at least 3-4 h, puppies were fed via an orogastric tube one of the three following formulas. 1) Bovine $\beta$-casein-based formula (Esbilac, Borden Products, Columbus, $\mathrm{OH})$ reconstituted in water $(20 \% \mathrm{w} / \mathrm{v}) ; 2)$ soy proteinbased formula (Isomil, Ross Laboratories, Columbus, OH), reconstituted in water to match the Esbilac in protein content $(30 \%$ $\mathrm{w} / \mathrm{v}$ ); and 3 ) canine milk (collected from bitches between 10 and 20 days postpartum and kept frozen until use). Esbilac was chosen because it is a choice formula for use in puppies in animal facilities. Two-wk-old puppies were fed $20 \mathrm{ml}$ and 4-wk-old 35 $\mathrm{ml}$ of milk. These volumes coincided with amounts of milk used in artificial feeding and raising of neonatal pups. The adult animals were fed $180-210 \mathrm{ml}$ of $\beta$-casein-containing formula (Esbilac liquid formula, Borden Products). 
Sample collection. Blood samples $(2.5 \mathrm{ml})$ were collected just before feeding and at $1,2,4$, and $6 \mathrm{~h}$ after feeding, into tubes containing EDTA $(1.5 \mathrm{mg} / \mathrm{ml})$, bestatin and thiorphan $(10 \mu \mathrm{g} /$ $\mathrm{ml}$ each). The plasma was separated immediately (at $4^{\circ} \mathrm{C}$ ) and stored at $-70^{\circ} \mathrm{C}$ until analyzed.

Extraction of $\beta$-casomorphin-7 from plasma. Plasma (1-2.5 $\mathrm{ml}$ ) was acidified with 0.1 volume of $1 \mathrm{~N} \mathrm{HCl}$ and centrifuged The supernatant was loaded on a Sep-Pak $\mathrm{C}_{18}$ column (Waters Associates, Milford, MA) that had been prewashed with $20.0 \mathrm{ml}$ of methanol followed by $20.0 \mathrm{ml}$ of water. The column was washed with $20.0 \mathrm{ml}$ of $4 \%$ acetic acid and $\beta$-casomorphins were eluted with $5.0 \mathrm{ml}$ of methanol. The eluant was evaporated to dryness by vacuum centrifugation (Speed vac, Savant Instruments, Inc., Hicksville, NY) and the residue taken up in a buffer consisting of $0.154 \mathrm{M} \mathrm{NaCl}, 0.025 \mathrm{M} \mathrm{Na}_{2} \mathrm{PO}_{4}, 0.1 \%$ Triton X100 and bacitracin $0.5 \mathrm{mg} / \mathrm{ml}, \mathrm{pH} 7.5$.

Estimation of $\beta$-casomorphin-7. $\beta$-casomorphin-7-like immunoreactivity was estimated in plasma extracts by RIA. Iodination of $\beta$-casomorphin-7 was accomplished as follows. Carrier-free freshly prepared $\mathrm{Na}^{125} \mathrm{I}$ (sp act $\left.2 \mathrm{Ci} / \mu \mathrm{mol}\right), 5-10 \mu \mathrm{l}, 4 \mathrm{mCi}$ was incubated with $2 \mathrm{nmol}$ of $\beta$-casomorphin- 7 and $0.1 \mathrm{ml}$ of $\mathrm{Na}_{2} \mathrm{PO}_{4}$ buffer $(0.25 \mathrm{M}, \mathrm{pH} 7.4)$ in tubes that were coated with $2 \mu \mathrm{g}$ of iodogen (Union Carbide Corp., Kalamazoo, MI). After 15 min at room temperature, the reaction mixture was transferred to a $0.1 \mathrm{ml}$ of $50 \mathrm{mM}$ Tris $\mathrm{HCl}$ buffer ( $\mathrm{pH} 7.4$ containing $0.1 \% \mathrm{BSA}$ ) to stop iodination. The mixture was applied to a $12.0 \mathrm{ml}$ column (disposable pipette) of Bio-Gel P2 (200-400 mesh) equilibrated with Tris $\mathrm{HCl}, 0.1 \%$ BSA. The column was eluted with the above Tris buffer and twenty $1.0 \mathrm{ml}$ fractions were collected. $\beta$-casomorphin-7 eluted at fractions $7-8$. The specific activity of the iodinated peptide was about $2 \mathrm{Ci} / \mu \mathrm{mol}$. $\beta$-casomorphin-7 antisera were prepared as described by Chang et al. (3)

RIA was carried out in buffer consisting of $0.154 \mathrm{M} \mathrm{NaCl}$, $0.025 \mathrm{M} \mathrm{Na}_{2} \mathrm{PO}_{4}, 0.1 \%$ Triton X-100, and bacitracin $0.5 \mathrm{mg} /$ $\mathrm{ml}, \mathrm{pH} 7.5$, at $4^{\circ} \mathrm{C}$ for $4 \mathrm{~h}$ with about $50,000 \mathrm{cpm}$ of ${ }^{125}$ I-labeled $\beta$-casomorphin, $5 \mu$ l of 200 -fold diluted (in above buffer) anti $\beta$ casomorphin antiserum and $25 \mu \mathrm{l}$ of solid phase immunoabsorbent (donkey-antirabbit IgG, sac-cel, Welcome Research, Triangle Park, NC) and sample extract in a total volume of 0.25 $\mathrm{ml}$. At the end of incubation, $4 \mathrm{ml}$ of the above RIA buffer was added and centrifuged at $3000 \mathrm{rpm}$ for $20 \mathrm{~min}$. The supernatant was aspirated and the precipitate was counted in a gamma counter (Packard, Sterling, VA, efficiency 70\%). Nonspecific binding $(3-5 \%)$ was determined in the presence of excess $\beta$ casomorphin (500 pmol/tube).

$\beta$-casomorphin-7 antisera had negligible cross-reactivity to $\beta$ casomorphin-5 and 4 and this specificity has already been documented (3). A linear relationship was obtained between 10 and $90 \%$ inhibition by ${ }^{125}$ I labeled peptide binding to the antibody over the range of concentrations of 0.017 to $5.0 \mathrm{pmol} /$ assay tube for $\beta$-casomorphin-7. The minimum detectable amount of $\beta$ casomorphin-7 using this assay was therefore $0.025 \mathrm{pmol} / \mathrm{ml}$.

Degradation of $\beta$-casomorphin-7. Plasma samples were collected (without addition of Bestatin and thiorphan) from 4-wkold puppies, $2 \mathrm{~h}$ after feeding $\beta$-casein-based formula. They were incubated at $37^{\circ} \mathrm{C}$ for 0 and $30 \mathrm{~min}$ with or without the addition of $10 \mathrm{pmol} / \mathrm{ml}$ of synthetic $\beta$-casomorphin-7. The incubation was terminated by the addition of 0.1 volume of $1 \mathrm{~N} \mathrm{HCl}$ and $\beta$-casomorphin-7 was extracted and analyzed as described above.

Column chromatography of BCMIR. Plasma samples collected $3 \mathrm{~h}$ after feeding $\beta$-casein-based formula to 4 -wk-old beagles were used for this experiment. BCMIR was extracted from the plasma as described above (about $60 \mathrm{ml}$, pooled from three puppies, using 30-Sep-Pak cartridges). The extracts were pooled and evaporated to dryness. The residue was reconstituted in $1.0 \mathrm{ml}$ of $0.04 \% \mathrm{v} / \mathrm{v}$ TFA. The dissolved material was applied on to a $1 \times$ $100 \mathrm{~cm}$ Bio-Gel P2 (200-400 mesh) column equilibrated with $0.04 \%$ TFA. The elution was carried out with $0.04 \%$ TFA at a flow rate of $2.4 \mathrm{ml} / \mathrm{h}$ and 140 fractions $(0.8 \mathrm{ml}$ each) were collected. After evaporation to dryness, the fractions were reconstituted in RIA buffer and analyzed for $\beta$-casomorphin immunoreactivity.

Statistical evaluation. Mean and the SEM were calculated. Statistical significance of means between groups was assessed by ANOVA. $p$ values of 0.05 or less were considered significant.

\section{RESULTS}

Extraction of $\beta$-casomorphin-7 added to $\beta$-casomorphin-free puppy plasma using Sep-Pak C18 columns resulted in high recovery rates. Even at the lower end of the RIA standard curve $(50 \mathrm{fmol} / \mathrm{ml}$ plasma), recovery rates were $78 \pm 2.3 \%$ (mean \pm SE, $n=18$ ), reaching $90 \pm 3$ at $170 \mathrm{fmol} / \mathrm{ml}$ plasma and $97 \pm 2$ at $500 \mathrm{fmol} / \mathrm{ml}$. Authenticity of the immunoreactivity was checked in the extract by dilutions in the range of 17 to $500 \mathrm{fmol}$ range. A linear curve, parallel to the standards, was observed.

After the 3- to 4-h fast, BCMIR was detected in the plasma of all beagle neonates studied, with the 2-wk-old puppies having a significantly higher base line (about $120 \mathrm{fmol} / \mathrm{ml}$ ) than the 4wk-old dogs (about $80 \mathrm{fmol} / \mathrm{ml}$ ) (Fig. 1). No similar base-line activity could be detected in any of the three adult dogs studied.

Effect of bovine casein-based formula feeding. Feeding of bovine formula increased BCMIR in both the 2- and 4-wk-old puppies (Fig. 1). The younger puppies significantly increased BCMIR by $4 \mathrm{~h}$ after feeding $(260 \pm 10 \mathrm{fmol} / \mathrm{ml})$ and had not decreased their levels back to base line by $6 \mathrm{~h}$. The percent change over base line were 31,113 , and 74 at 2,4 , and $6 \mathrm{~h}$, respectively. The older puppies significantly increased their levels by $2 \mathrm{~h}(140 \pm 10 \mathrm{fmol} / \mathrm{ml})$ and still had levels higher than base line by $6 \mathrm{~h}$ (Fig. 1). The percent change over base line in older puppies were 102,99 , and 79 at 2,4 , and $6 \mathrm{~h}$, respectively. Although higher levels were obtained in the 2-wk-old puppies, the percentage change in these puppies were found to be similar to those in the 4-wk-old puppies. No BCMIR was detected in adult dogs after bovine formula intake.

Effect of canine milk feeding. Feeding of canine milk also increased BCMIR in plasma of both groups of puppies (Fig. 2).

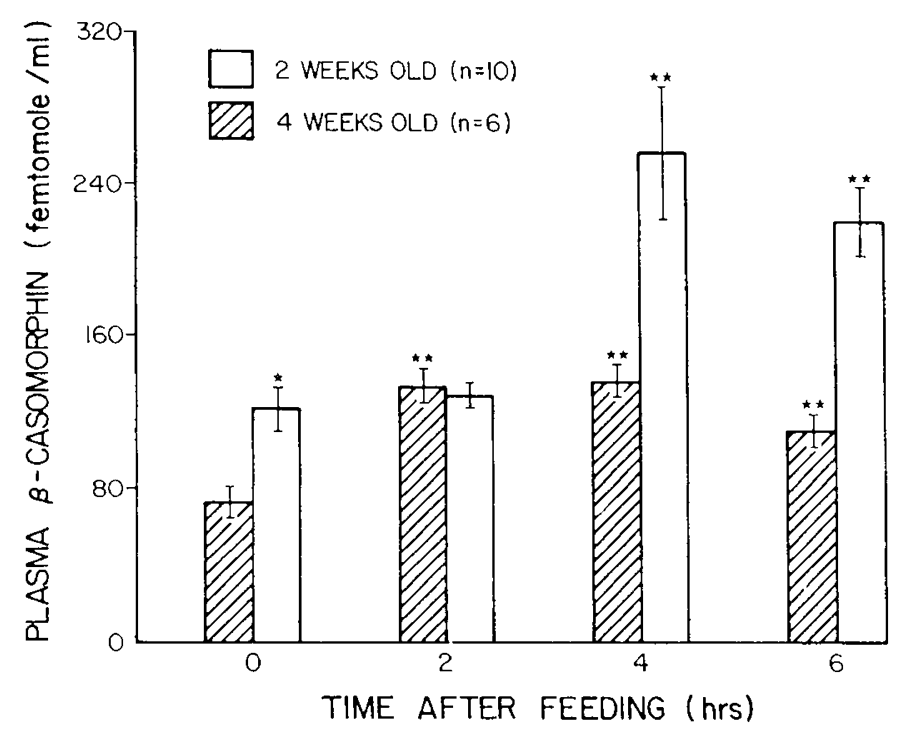

Fig. 1. Plasma $\beta$-casomorphin-7 immunoreactivity levels at baseline ( 0 time) and 2, 4, and $6 \mathrm{~h}$ after feeding of bovine casein-based formula. Crossed bars represent 4-wk-old and open bars represent 2-wk-old puppies. Numbers in parentheses indicate number of puppies studied at all time points except for $6 \mathrm{~h}$, where $n=6$ for both age groups. Values are mean $\pm \mathrm{SE}$ of the mean. ${ }^{*} p<0.05$, refers to comparison of base-line values between 4 - and 2 -wk-old puppies. ${ }^{* *} p<0.05$ refers to comparison of base-line values with 2,4 , and $6 \mathrm{~h}$ after feeding for both age groups. 


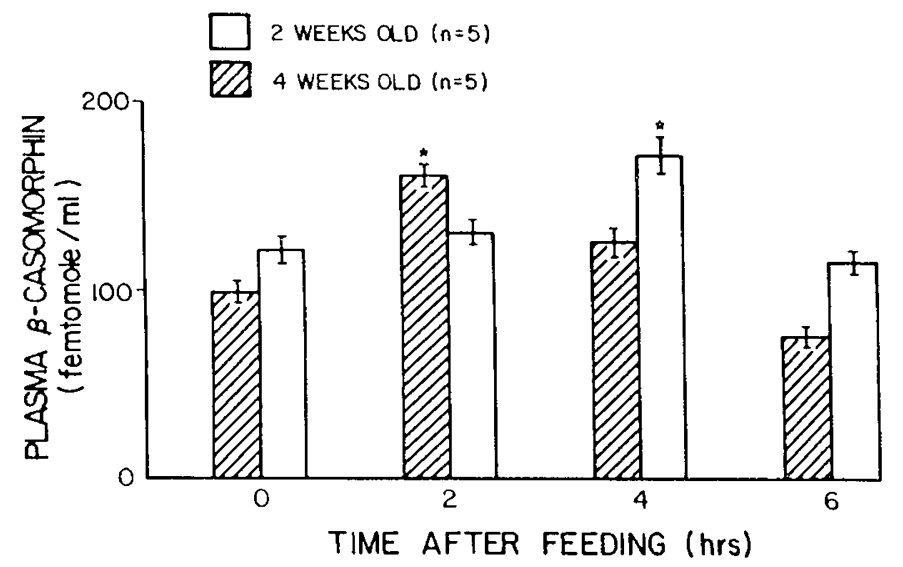

Fig. 2. Plasma $\beta$-casomorphin immunoreactivity levels during baseline (0 time) and at 2, 4, and $6 \mathrm{~h}$ after feeding of canine milk. Crossed bars represent 4 -wk-old and open bars represent 2-wk-old puppies. Numbers in parentheses indicate number of puppies studied. Values are mean \pm SEM. ${ }^{*} p<0.05$ refers to comparison of base-line values with values at 2,4 , and $6 \mathrm{~h}$ after feeding for both age groups.

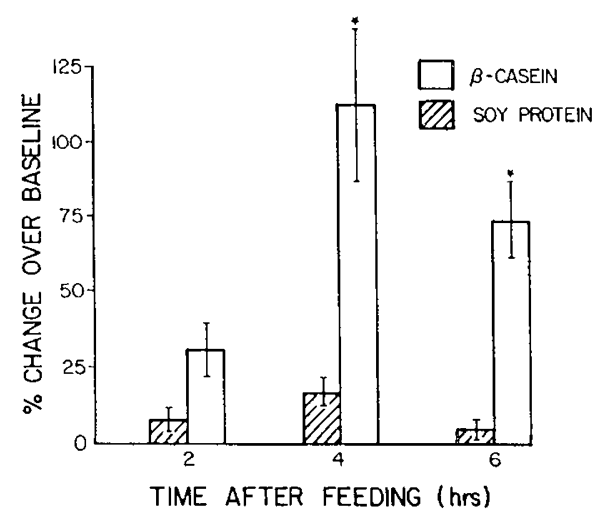

Fig. 3. Increase in plasma $\beta$-casomorphin-7-like immunoreactivity of 2 -wk-old puppies is specific to casein intake. $\beta$-casomorphin-7 immunoreactivity is expressed as percent change over base line for 2 -wk-old puppies. Number of puppies studied with soy protein and casein feeding were $n=5$ and 10 , respectively. Values are mean \pm SE. ${ }^{*} p<0.05$ refers to comparison of base-line values with values 2,4 , and $6 \mathrm{~h}$.

The magnitude of increase, however, was smaller than that found after bovine formula feeding. The peak values were obtained at $2 \mathrm{~h}$ after feeding for the older puppies ( $62 \%$ over base line) and at $4 \mathrm{~h}$ for the younger group (42\%). This pattern of increase after canine milk intake was similar to that found after bovine milk. In contrast to bovine milk feeding, however, plasma BCMIR returned to base-line values by $6 \mathrm{~h}$ after canine milk feeding in both groups of puppies.

Effect of soy protein milk feeding. Feeding soy protein-based formula to either group of puppies had little effect on plasma BCMIR levels. Figures 3 and 4 show that the percent change in BCMIR levels is small (statistically insignificant) post-soy protein in both age groups but is of the order of $30-100 \%$ for the bovine formula in both 2- and 4-wk-old puppies. Three of the 2-wk-old puppies that received soy protein were also studied with bovine casein. These showed an increase in BCMIR levels after the bovine formula but little after soy.

Effect of enzymatic hydrolysis in plasma. BCMIR was resistant to proteolysis in puppy plasma because incubation for $30 \mathrm{~min}$ at $37^{\circ} \mathrm{C}$ did not result in loss of immunoreactivity $(160 \pm 2 \mathrm{fmol} /$ $\mathrm{ml}$ at 0 time versus $170 \pm 20 \mathrm{fmol} / \mathrm{ml}$ at $30 \mathrm{~min}$ ). However, synthetic $\beta$-casomorphin-7 added to the same plasma was rapidly

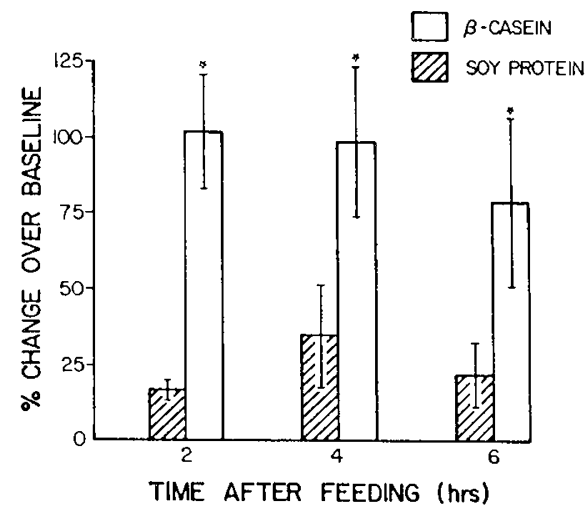

Fig. 4. Increase in plasma $\beta$-casomorphin-7-like immunoreactivity of 4 -wk-old puppies is specific to casein intake. $\beta$-casomorphin-7 immunoreactivity is expressed as percent change over base line for 4-wk-old puppies. Number of puppies studied with soy protein and casein feeding were $n=3$ and 6 , respectively. Values are mean \pm SE. ${ }^{*} p<0.05$ refers to comparison of base-line values with values at 2,4 , and $6 \mathrm{~h}$.

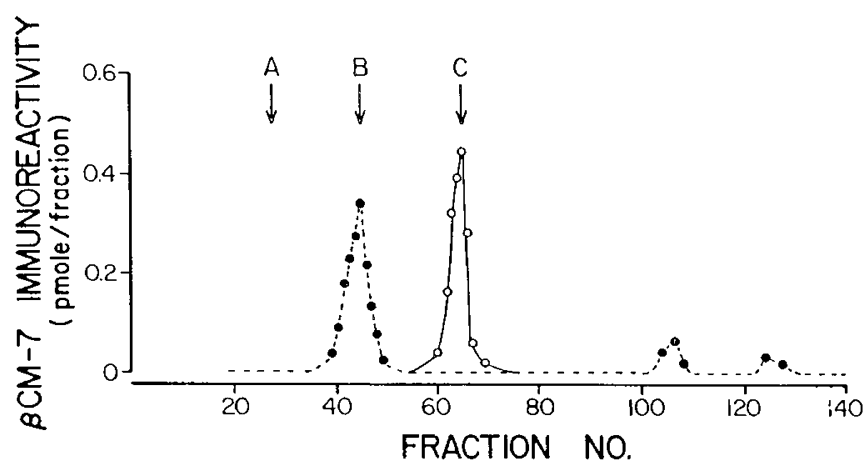

Fig. 5. Elution pattern on Bio-Gel P2 column of $\beta$-casomorphin-7 immunoreactive material from plasma of beagle neonates after $\beta$-caseinbased formula intake. $\beta$-casomorphin-7 immunoreactivity is expressed in $\mathrm{pmol} /$ fraction. Broken line with solid circles represents elution pattern of plasma extract. Solid line with open circles represents the synthetic $\beta$ casomorphin-7 elution position. Arrows indicate peak elution position for void volume $(A)$, plasma extract $(B)$, and synthetic $\beta$-casomorphin-7 $(C)$.

degraded (94\% lost by $30 \mathrm{~min}$ post-incubation) under similar conditions. Addition of adult plasma to puppy plasma did not affect the stability of BCMIR, although synthetic $\beta$-casomorphin7 was degraded also by adult dog plasma.

Chromatographic characterization of BCMIR. BCMIR derived from plasma of three puppies eluted on the Bio-Gel column as a single major peak. This suggested homogeneity (Fig. 5). The position of the major immunoreactivity peak was in between the void volume (mol wt $>1800)$ and synthetic $\beta$-casomorphin-7 $(\mathrm{mol} \mathrm{wt}=790)$.

\section{DISCUSSION}

For the first time our data document the relation between milk intake and plasma $\beta$-casomorphin-7 immunoreactive peptide levels in dogs as a function of age. To a large extent, our ability to observe differences between age groups and with time was enhanced significantly by the high recovery rates of BCMIR from plasma using a new extraction technique. For comparison, our extraction yielded a 4-fold increase in $\beta$-casomorphin-7 recovery rate over that of Umback et al. (11) using charcoal. From a feasibility standpoint, this advance was important because we 
could limit the amount of blood sampled from small young animals.

At least four conclusions can be drawn from our results. First, there is an increase in $\beta$-casomorphin- 7 immunoreactive peptide in the plasma of puppies but not in adult dogs after milk intake suggesting that this phenomenon is maturation related. Second, this increase in BCMIR is specific to the presence of $\beta$-casein in milk because BCMIR levels did not increase in puppies with soy protein (non-casein) milk. Third, the BCMIR molecule from bovine milk is larger than a seven amino acid peptide, but probably contains no more than $12-13$ amino acids. Fourth, differences in BCMIR levels after canine versus bovine milk suggest differences in composition of BCMIR obtained from bovine versus canine milk.

Since previous studies have demonstrated the presence of $\beta$ casomorphins in the intestine of animals and humans $(9,10)$ our current data in puppies strongly suggest that BCMIR was cleaved in the gastrointestinal tract and transported to the blood stream. Proteases and peptidases of the brush border membranes of the small intestinal mucosa are capable of releasing peptides such as $\beta$-casomorphins from larger precursors ( $\beta$-casein) (15). For example, $\beta$-casomorphin-7, a heptapeptide with an amino acid sequence of Tyr-Pro-Phe-Pro-Gly-Pro-Ile, corresponds to amino acids 60 to 66 of the bovine $\beta$-casein chain.

The intestinal mucosa of the newborn has been reported to be permeable even to relatively large peptides and proteins (13). This is attributed to their immature tight junctions through which peptides cross, thereby escaping hydrolysis. With development of the intestinal mucosa, the passage of such molecules is restricted. Thus, our results demonstrating the presence of BCMIR in puppies but not in dogs are consistent with maturation of the intestinal mucosa (13).

Once in circulation, the survival of the $\beta$-casomorphins is dependent on the presence and action of an enzyme system similar or identical to dipeptidyl-peptidase (16). Such an enzyme, although not directly assayed in our studies, is highly active in puppies and adult beagle plasma, as we demonstrated in our degradation studies of $\beta$-casomorphin-7. This amino-peptidase acts on proline residues in position 2 of the amino-terminus, releasing dipeptides sequentially. The fact that BCMIR of beagle neonates was totally resistant to enzymatic degradation by puppy as well as adult dog plasma supports the conclusion that BCMIR is not $\beta$-casomorphin-7. Moreover, because $\beta$-casomorphin-7 antibody has very little cross-reactivity to $\beta$-casomorphin- 4,5 , and 6 , it is unlikely that BCMIR is smaller than $\beta$-casomorphin7. Our chromatographic studies strongly suggest that BCMIR (derived from three puppies) was a homogeneous peptide with 12 or 13 amino acid residues. Inasmuch as the anti- $\beta$-casomorphin serum used in the assay recognizes the carboxyl-terminus of the peptide molecule, the additional amino acids are likely to be on the amino-terminus side, thus protecting the proline residue in the second position of the $\beta$-casomorphin-7 aminoacid sequence. An alternative explanation for the long lasting elevation of BCMIR in puppies is the continued production of BCMIR from large precursor molecules in plasma.

BCMIR levels after canine milk feeding were different from those of bovine milk. The explanation for these differences is not readily clear and our studies were not aimed at determining the reasons for such differences. It is relevant to point out that the amino acid composition of canine $\beta$-casein is not known at present.

Administration of $\beta$-casomorphins has been shown to exert several important physiologic effects (4-7). $\beta$-casomorphins modulate secretion of postprandial insulin (5) and somatostatin (6) in dogs and can elicit analgesia (4). In addition, these peptides alter active intestinal electrolyte transport (17). Whether these peptides cross from blood to cerebrospinal fluid depends on the permeability of the blood brain barrier and on transport mechanisms $(19,20)$. The circumventricular organs $(e . g$. the choroid plexus) are considered to possess leaky capillary endothelial cell layers. In the young with a poorly developed barrier, this issue may take on added significance. Our own unpublished studies have shown that peripherally administered $\beta$-casomorphin-7 can induce physiologic changes in puppies at $2 \mathrm{wk}$ of age $(n=4)$. These included an immediate (within 1-2 min) drop in blood pressure and a shallow rapid respiration. Of interest in this regard are our previous observations (18) in adult dogs showing similar results after central injections of both morphiceptin and morphine.

We show in this report that milk, a source of $\beta$-casein, may be a source of exorphins in puppies. There are at least two observations that are relevant in this regard: 1) $\beta$-casomorphin- 5 and 7 and morphiceptin (Tyr-Pro-Phe-Pro- $\mathrm{NH}_{2}$ ) can be cleaved from larger molecules such as BCMIR in the blood or other tissues such as brain (3), and 2) these shorter $\beta$-casomorphins are well known selective and powerful $\mu$-opioid agonists $(4,18)$. Whether BCMIR itself has opioid activity is not known, but its cleavage products do $(2,3)$.

There are two clinical conditions that are associated with high plasma $\beta$-casomorphin levels (21). Lindstrom et al. (21) reported very high levels of a peptide with electrophoretic and chromatographic characteristics similar to those of $\beta$-casomorphin-7 in plasma a cerebrospinal fluid of women with severe postpartum psychosis. High levels of $\beta$-casomorphin-7-like immunoreactivity has also been demonstrated in plasma of newborn infants with apnea (22). Moreover, because the stress of labor and delivery can induce the release of endorphins and because endorphin levels are higher in the first days of life (23), some have speculated that milk intake in early life may prevent withdrawal symptoms.

In summary, using a new extraction technique, we have shown that $\beta$-casomorphin-7 immunoreactive material increases in the plasma of puppies, but not of dogs after $\beta$-casein-based milk (canine or bovine) intake. BCMIR remained in the plasma of puppies for hours after feed. Our chromotographic studies show that BCMIR is longer than a heptapeptide molecule and probably consists of 12-13 amino acid residues.

\section{REFERENCES}

1. Henschen A, Lottspeich F, Brantl V, Teschemacher H 1979 Novel opioid peptides derived from casein ( $\beta$-casomorphins) II. Structure of active components from bovine casein peptone. Z Physiol Chem 360:1217-1224

2. Brantl V, Teschmacher H, Blasig J, Henschen A, Lottspeich F 1981 Opioid activities of $\beta$-casomorphins. Life Sci 28:1903-1909

3. Chang KJ, Su YF, Brent DA, Chang JK 1985 Isolation of a specific opiate receptor peptide, morphiceptin, from an enzymatic digest of milk proteins. J Biol Chem 260:9706-9712

4. Chang KJ, Cuatrecasas P, Wei ET, Chang JK 1982 Analgesic activity of intracerebroventricular administration of morphiceptin and $\beta$-casomorphins: correlation with the morphine $(\mu)$ receptor binding affinity. Life Sci 30:1547-1551

5. Schusdziarra V, Schick A, Fuente AD, Specht J, Klier M, Brantl V, Pfeiffer EF 1983 Effect of $\beta$-casomorphins and analogs on insulin release in dogs. Endocrinology 112:885-889

6. Schusdziarra V, Schick A, Fuente AD, Holland A, Brantl V, Pfeiffer EF 1983 Effect of $\beta$-casomorphins on somatostatin release in dogs. Endocrinology 112:1948-1951

7. Wei ET, Leo A, Chang JK 1980 Cardiovascular effects of peptides related to the enkephalins and $\beta$-casomorphin. Life Sci 26:1517-1522

8. Panksepp J, Normansell L, Siviy S, Rossi J III, Zolovick AJ 1984 Casomorphins reduce separation distress in chicks. Peptides 5:829-831

9. Meisel H 1986 Chemical characterization and opioid activity of an exorphin isolated from in vivo digests of casein. FEBS Letters 196:223-227

10. Svedberg J, Haas JD, Leimenstoll G, Paul F, Teschmacher H 1985 Demonstration of $\beta$-casomorphin immunoreactive materials in in vitro digests of bovine milk and in small intestine contents after bovine milk ingestion in adult humans. Peptides 6:825-830

11. Umbach M, Teschmacher H, Praetorius K, Hirschhauser R, Bostedt H 1985 Demonstration of a $\beta$-casomorphine immunoreactive material in the plasma of newborn calves after milk intake. Regul Peptides 12:223-230

12. Teschmacher $\mathrm{H}$, Umbach $M$, Hamel U, Praetorius $K$, Hilger GA, Brandtl $V$ Lottspeich F, Henschen A 1986 No evidence for the presence of $\beta$-casomorphins in human plasma after ingestion of cow's milk or milk products. J Dairy Res 53:135-138 
13. Thomson ABR, Keelan M 1986 The development of the small intestine. Can J Physical Pharmacol 64:13-29

14. Meisenberg G, Simmons WH 1983 Peptides and the bloodbrain barrier. Life Sci 32:2611-2623

15. Kerchner GA, Geary LE 1983 Studies on the transport of enkephalin-like oligopeptides in rat intestinal mucosa. J Pharmacol Exp Ther 226:33-38

16. Kreil G, Umbach M, Brantl V, Teschmacher H 1983 Studies on the enzymatic degradation of $\beta$-casomorphins. Life Sci 33:137-140

17. Hautefeuille M, Brantl V, Dumontier AM. Desjeux JF 1986 In vitro effects of $\beta$-casomorphins on ion transport in rabbit ileum. Am J Physiol 250:G92G97.

18. Haddad GG, Schaeffer JI, Chang KJ 1984 Opposite effects of the mu- and delta-receptor agonists on ventilation in conscious adult dogs. Brain Res
323:73-82

19. Ermisch A, Ruhle HJ, Landgraf R, Hess J 1985 Blood-brain barrier and peptides. J Cereb Blood Flow Metabol 5:350-357

20. Banks WA, Kastin AJ 1987 Saturable transport of peptides across the bloodbrain barrier. Life Sci 41:1319-1338

21. Lindstrom LH, Nyberg F, Terenius L, Bauer K, Besev G, Gunne LM, Lyrenas S, Lund GW, Lindberg B 1984 CSF and plasma $\beta$-casomorphin-like opioid peptides in postpartum psychosis. Am J Psychiatry 141:1059-1066

22. Spitzer A, Butler S, Fox WW, Chang KJ 1988 Beta casomorphin-effects of opiate like peptides from milk protein on apnea of infancy. Pediatr Res 22:450A

23. Burnard ED, Todd DA, John E, Hindmarch KW $1982 \beta$-Endorphin levels in newborn cerebrospinal fluid. Aust Pediatr J 18:258-263

\section{Announcement}

\section{Charles E. Culpeper Foundation Scholarships in Medical Science}

The Charles E. Culpeper Foundation is currently accepting applications for its 1990 Scholarships in Medical Science Program designed to support the career development of academic physicians.

Up to three awards of $\$ 100,000 / y$ for 3 y will be made to United States medical schools on behalf of candidates who are U.S. citizens, who have received the M.D. degree from a U.S. medical school in 1981 or later, and who are judged worthy of support by virtue of the quality of their research proposals. All scientific research relevant to human health is eligible for consideration. No institution may nominate more than one candidate.

In selecting awardees, emphasis will be on identifying young physicians with clear potential for making substantial contributions to science as academic physicians. Since January 1988, six physicians have been selected as Charles E. Culpeper Foundation Medical Scholars, three each in the years 1988 and 1989.

Deadline for applications is August 15, 1989. Awards will be announced by January 15, 1990, for activation on or about July 1, 1990. Application forms and instructions may be obtained by contacting the Charles E. Culpeper Foundation, 866 United Nations Plaza, New York, NY 10017. 